\title{
New-Regionalism: The Slipknot of the Two Rival Trends?
}

\author{
By Emre Baysoy*
}

The world's security structure is facing a qualitative change and there is an ongoing search for achieving equilibrium for global security. There is a need to analyze what the catalytic determinants of the contemporary security issues are. Examining the issue of regionalism may be helpful to reveal those determinants to some extent. The fact that new threats to the new security environment are regional in scope and effect, regions and regionalism can be considered as the prominent unit of analysis level. Especially, regionalism may suggest a theoretical framework for assessing the two main trends of globalization which are consolidation and disintegration. In an effort to widen the scope of regionalism, this study firstly overviews the regionalism studies of the Cold War era. Secondly, the 'new-regionalism' and the alternate approaches within the new-regionalism studies are mentioned. Finally, it is offered that how a regional perspective can enrich the inquiry of the catalytic determinants. The purpose of this paper is to introduce and explain the theoretical basis of new-regionalism in security studies and to contribute to the acceleration of the discussions since regionalism can be the slipknot of the consolidation and disintegration trends both in theory and in practice.

Keywords: Global Security, Globalization, New-Regionalism, Regionalism.

\section{Introduction}

The issue of security can be studied in three different contexts. These contexts can be classified as: conceptual, structural and geopolitical. Although these frameworks are compatible with each other either one offers different methods. The conceptual framework can be examined in two subfields. At the first subfield, security can be identified as an abstract concept that the "situation of being well" or "being away from fear and threat". At the second subfield, security is a referential concept. Each dimension of the security becomes meaningful with reference to specific issues. These specific issues are the main problems and threats. As a referential concept, security can be classified as two subfields as functional and object reference. At the functional dimension, there are political, economic, socio-cultural and military issues.

These mentioned referential points change and vary according to the change of the international structure. In other words, the problems and threats are redefined in relation to the new developments. Since every international structure has its own priorities and issues, new threats and new threat perceptions occur according to those priorities and issues. Therefore, in order to identify new threats and to take precautions, the qualitative changes in the international security

\footnotetext{
*Assistant Professor, Namık Kemal University, Turkey.
} 
structure should be determined, in line with these changes and developments, every system and/or unit (state-group-organization) endeavor to develop its own mechanism of security perception. At this point, it can be said that since threats and problems are getting a regional character, a regional perspective is needed to generate required precautions.

Secondly, the structural context is consisting of national, global and regional levels. At the regional level Europe, Middle East, Atlantic-Pacific axis, Central Asia, Caucasus and the Far East consist the conventional focal points. The third, the geopolitical context is consisting of changing factors such as economic and hegemonic orders. Changing factors can be studied both at global and regional level. Regional theory, although focuses on a regional level, regards other levels as well and designate which level is the main determinant according to the time and space. That is why; regional research level is not only to examine the events and issues of the selected level but also to inquire other levels as well.

This paper mainly focuses on the new regionalism with the assumption that construction of the new political entities or units may be based on regional dynamics, rather than internal dynamics of a state. In reference to David Singer's (1961) classical text "The Level of Analysis Problem", this study argues that in contemporary era the regional layer becomes weigh favorably against interstate and domestic levels in conjuncture with the global level. But this is not to say that interstate and domestic levels have lost their significance, rather they become meaningful only in a regional context.

It is possible to say that after the Arab Spring, Northern Africa and Eastern Mediterranean is in structural turmoil and this turmoil has not come to an end. In such a situation new regionalism has a potential to provide the needed theoretical base in search for a new political structures and entities. This is not to say this paper is offering that new regionalism is or should be the answer. In contrary, new regionalism has great deficits in terms of democracy and/or people will, regarding how much it considers the peoples' interests in regard to the stability of energy supply and the security of trade routes etc. However, since new regionalism is a part of the reality it should be considered and highlighted again in such a perspective. Yet, evaluation of a specific region such as the Middle East, Eastern Mediterranean or Far East is out of the scope of this study. Still, although, the article is limited by a theoretical and conceptual framework, it is possible to say that this context is best visible at Northern Africa and Eastern Mediterranean. The relation with the new regionalism and Eastern Mediterranean's actual politics is another study's subject. Finally, the article does not assert that it covers all the old and new regionalism literature review, still it will point out some basic approaches and different conceptualizations of regionalism.

\section{Concepts of Region and Regionalism}

The "region" has no one single definition. Different disciplines and different contexts define region in various forms. A region can be defined as geographically, functionally (Mansfield and Milner 1999), politically and economically (Fishlow 
and Haggard 1992, as cited in Mansfield and Milner 1999). However, a very general definition of a region can be defined as a space in which there is an observable interaction between the actors and institutions in a specific geography (Gunnarson 2000). Therefore, in general, a region can be understood as an association of a group of states on the basis of geographical closeness (Mansfield and Milner 1999).

On the other hand, regionalism is defined as a region's capacity to be a particular actor (predicated on the capacity of the regional cooperation among the regional actors) that act as part at the world stage (Gunnarson 2000). However, there can also be unstructured security regions because of the instability of region states. In such regions, there occurs reluctance of ex-regional states and a strong international configuration that overlays regional powers. In this sense security regions also have their own power centers and sorts of polarity. Thus, there emerges a standard security region in which there are more than one regional actors. These concentric security regions are dominated by a single actor (Y1lmaz 2008: 66). Central Asia and the Caucasus can be given as examples to concentric security regions at the era of Soviet Union.

The classification of different regional approaches can be made in various ways. For example, according to economists regionalism refers to the creation of a common economic region which can be by trade and economic relations. However, regarding regionalism only with economic criteria can fail to notice the political dimensions of the issue (Mansfield and Milner 1999). As to international relations and security studies, regionalism is defined as the relationship of a group of states because of a geographical proximity. At regional security, security of states is so interconnected that neither one regards its own security separate from the others and security refers to natural, cultural, geographical or historical ties. (Caşın et al. 2007: 113-4)

Regionalism is also a term that contains totally different developments and processes (Hurrell 2007: 130). That is why to dwell shortly on the historical evolution of regionalism may help to classify different conceptualizations and functionalizations of regionalism. Both as a concept and as a praxis, the meanings of region and regionalism are in closely bound to political conjunctures. This arises from the fact that regionalism has a functional and instrumental dimension.

\section{Regionalism before and during the Cold War}

Before the emergence of regionalism as a theoretical approach and as a systematical way of analysis, regions could only find a place in world politics for practical purposes. Starting from the first political communities, economic and political relations have regional focus because of the technological, commercial and communicational restrictions (Hurrell 2007: 128-9). Also, the regional focus was important in the emergence of every imperial system. Thus, in the pre-modern era, the world system widened region by region until it took its contemporary shape and disconnected regions disappeared (Buzan and Wæver 2003). 
With the dominance of the bipolar world system, the regional level was ignored by the Cold War literature (Hurrell 2007: 133). At that era regionalism functionalized only as a part of the containment policy in a militaristic and strategic sense (Mittelman and Falk 2000: 6). Still, at the first part of the Cold War, there were some developments that emphasize regions and regional level. For instance, $24^{\text {th }}$ article of the GATT agreement did not regard tariff unions and free trade zones as commercial discrimination. Again, $52^{\text {nd }}$ article of the United Nations Charter supported regional security practices (Hurrell 2007: 130). However, regions are regarded in the framework of the bipolar system. Although there were local security systems, those systems could not go beyond determining how external powers would affect the region (Buzan 1991, Vayrynen 2003: 28).

With the détente era, international system decreased the pressure over the regions and regional problems started to enter into world agenda. The first wave in the regional studies emerged after the independence movements of the 1960s. With the new regional problems, a search for a new order begun and this process continued in the 1970s (Kelly 2007: 202). Especially with the demands of the "Third Worldism" and with the rise of the "South" regionalism gained a normative character from the very beginning.

Apart from regions were on the front burner, regionalism started to gain importance as a theoretical mode of analysis. However, the general systems theory which was dominant at IR and IS studies, were implemented to the regional level only (Hurrell 2007: 133, Kelly 2007: 204). From Morton Kaplan's (1957) and Ernest B. Haas's (1958) "General System" and sub-systems approach has emerged. Sub-systems were understood as structures that carry the general characteristics of the international system but show some specific socio-cultural features (i.e., the Middle East) (Boals 1973: 403 as cited in Kelly 2007: 202).

The general system based by neo-realism of Kenneth Waltz became dominant especially after 1979. But again, regions were accepted as sub-systems only. It is accepted that the specifications of sub-systems were important while connecting with the general system (Kelly 2007: 203). It is possible to say that rather than examining regions and regional studies, the aim was to clarify how sub-systems could be controlled closely by the general system. In this way in times of the Cold War, "super-regions" (NATO and Warsaw Pact) (Vayrnen 2003: 26) were created and the main importance was given to the international system's stability in theory and in practice.

\section{New Regionalism}

The political and the economic developments of the 1970s and 1980s transformed the sub-system security studies. The ending of détente, the failure of OPEC and New International Economic Order (NIEO) and the depth crisis; ending of Third Worldism have prioritized the international system once more. These developments have also reflected the security studies. Neither the neorealism of Kenneth Waltz (1979) nor a political-economic version of Robert Gilpin's (1981) neo-realism gave importance to regional studies. Nevertheless, 
after the end of the bi-polarity, regions and regionalist studies started to find place in the world politics (Kelly 2007: 204). The reason for this can be seen as the regional sub-systems analysis helped to reduce the ambiguity of world politics of the era (Thompson 1973: 91).

During and after the Cold War, three perspectives have started to be shaped including regionalism (Buzan and Waever 2003). These perspectives can be classified as neo-realism, globalism, and regionalism (Caşın et al. 2007: 113). First of all according to neo-realism, although the structure of power has changed at the global level, facts like the balance of power and polarity continue to be effective in the new era too. The polarization of power continues to exist as unipolar, multipolar and sometimes in a mixed way and the distribution of the material power still determines the international structure. Therefore, the international system continues to be state-centric. In the context of regionalism, neo-realism gives secondary importance to regionalism and in terms of actor-system discussion, give the importance to the determinism of the system (Buzan and Waever 2003).

Globalism, on the other hand, argues that international system is not statecentric anymore and world politics is becoming more and more independent from space (de-territorialization of world politics) and as a result of technological developments in communication, a cosmopolitan world society is emerging (Buzan and Waever 2003). However, globalism has two contradictory approaches as neo-liberal and Marxist. Although both approaches explain the international system in terms of the dichotomy of center and periphery, according to Marxism the balance which the bi-polarity had provided fell into decay as a result of West's growing hegemony by militaristic and economic power over the periphery with the help of organizations like NATO, EU, and WTO. Thus, the vulnerability of the periphery is the biggest threat to international security. In contrary according to neo-liberalism, the articulation of the "non-integrated gap" (Barnett 2005) (Second and Third World countries) to the world society constitutes the main agenda of international security (Barnett 2005). To reach this aim Inter-Govermental Organizations are as important as Non-Governmental Organizations.

The most important characteristic that differentiates regionalism from other approaches is regionalism accepts region as both a level of analysis and also a unit of analysis (Buzan and Waever 2003, Korkmaz 2010: 137). Regionalism has also neo-liberal, neo-realist and the hybrid approach in itself. In other respects, it is possible to classify different versions of regionalism according to the issues they study and methods they use. Thus, it is possible to classify regionalism into four main groups. The ones that emphasize the structural features of the international system; structuralists; ones focus on the state level and the ones who regard region as a governance level (Kelly 2007: 197-229, Hurrell 1995: 37-73, Kubicek 2009: 238 as cited in Korkmaz 2010: 144). Mearsheimer can be seen as representative of the international system approach among regionalism. According to Mearsheimer, every state's aim is to establish hegemony over the international system. However, since this aim is hard to achieve (even for the US), regional hegemony is state's prior goal. To set this goal states to seek power directly or they try to prevent other state's gaining power indirectly (Mearsheimer 2001, Toft 2005). Similar with 
Mearsheimer, Katzenstein (2005) also emphasizes the dominance of the international system over the sub-systems and he argues that there are six major regions which are Europe, East Asia, Africa, Latin America, Middle East and South Asia. Katzenstein's regions also overlap with the US's military zones. This point is compatible with the view that regions do not emerge by themselves but a result of a hegemon (Kelly 2007: 222).

The structuralist approach focuses on how regions emerge with the identification of norms and identities by governments, civilian groups, and businessmen. Structuralism assesses regionalism as a leverage to achieve political and economic ends (Vayrynen 2003: 26-7). According to the ones who regard regions as a governance level, regionalism is an inner part of contemporary multilayered governance (Thakur and Langenhove 2006: 235). According to governance approach, regionalism is a problem-solving understanding (Thakur and Langenhove 2006: 233). For example, with the decreasing importance of the threats at Asia-Pacific region, regional governance notion is coming forward rather than security regions (Dieter 2009).

Regionalist studies can also be classified as physical regionalism and functional regionalism (Vayrynen 2003: 27). Functional studies spotlight the nonstate actors by focusing on the non-territorial factors like culture and market. For instance, Newman (1999) emphasizes the processes of identity production in relation to the abrasive effect of globalization. Accordingly, for this perspective, for a creation of a region, it is enough to resemble on any economic, environmental, political or cultural issue. Last but not the least, Bjorn Hettne (2008) regards regions as a totally new political actor and according to him there is a historical transformation is going on and regions replace the states (Kelly 2007: 206): "Regionalism is the key aspect of the post-Cold War Era" (Hettne 2008: 88).

Since regionalist studies are various, it is hard to make a simple classification of them. However, it is possible to argue that the most valid and reliable classification may be made between physical regionalism and functional regionalism. Still, there are different categories within these regional perspectives. For example, Kelly classifies Buzan, Lemke, and Lake as formal-positivist; Haas (1958), Falk and Mendlovitz (1973) as new functionalist and integrationist; Hettne as normative new-functionalist (Kelly 2007: 206). Lastly, Hentz (2003), Marry Farrell et al. (2005) mentions cognitive regions (Kelly 2007: 205).

Formal and positivist namely physical regionalism (neo-realism) continue to give importance to the relationship between security and space. Geographical proximity is at the heart of the analysis and geography is the main determinant of state's power projections (Kelly 2007: 205). Physical regionalism emphasizes that states turn territories to account politically and economically (Vayrynen 2003: 27). Agnew and Corbridge (1995) tried to make a synthesis of the approaches. However, it should be noted that the transaction from physical regionalism to functional regionalism is also a political and economic process, and is a result of improvement of the interaction capacity in the system (Vayrynen 2003: 28). At a low capacity (international) system, physical features come forward and a subsystem dominant order is achieved (Buzan et al. 1993 as cited in Vayrynen 2003: 28). 
Another alternative approach to regionalism comes from Copenhagen School. According to Barry Buzan geography and spatial proximity is crucial but not adequate in the formation of regions. Copenhagen school argues that if there is no issue of security in any given geography that is to say if there are patterns of rivalry and cooperation (as Africa), we cannot talk about a region there. The intensity of interaction is the main criteria of regions (Kelly 2007: 205).

In the 1960s and 70s, it was relatively easy to define regions and determine their boundaries operationally (Moon 1998: 338, Kelly 2007: 204). NewFunctionalism, on the other hand, tries to solve this problem by focusing on the relevant issue in concern rather than being dependent on geography (Kaztzenstein 2002 as cited in Kelly 2007, Vayrynen 2003: 25). According to this view, the main criterion of a region is an intense relationship in a common ground (Kelly 2007: 203). In contrast, classical regionalism tried to create holistic, macro-regions (Kelly 2007: 204). As a synthesis of these two views, Thompson (1973: 98-101) argues that in order to talk about a region there should be regular and intense interaction, geographical proximity, the ability of the sub-regions to be an actor and at least two actors. (Kelly 2007: 204).

One remarkable model regarding regionalism is Barry Buzan and Ole Weaver's (2003) "Regional Security Complex" (RSC). RSC can be defined as a condition in which group of state's most important security perceptions and concerns are inseparable from each other (Buzan and Weaver 2003: 12). Decisive structure and dynamics of RSC are determined by the states in that structure. According to the theory, it is normal to have regional security structure in an anarchic system. In other words, RSC is an inevitable outcome of anarchic structure (miniature anarchy). Besides, RSC determines how ex-regional actors' penetration to the region. The interior dynamics of RSC can be ranged from amity to enmity. If the problems of the region are solved and regional integration is achieved, the power structure of region transforms. On condition that conflict resolutions in a region get permanent and get institutionalized, there emerges a security regime and this (as EU did) leads to a pluralistic security community.

Copenhagen School argues that region is the level at which conflict and cooperation of states are observable (Buzan and Waever 2003). This approach depends on two assumptions. First, the absence of superpower rivalry has changed the character of global power interests and lost its influence. Second, with the moribund of common threat perception of bi-polarity, states' near environment and their own interior dynamics became more important. That is why the question of "what constitutes the regional level?" became one of the main questions of security studies. However, although the regional level is emphasized, from the notion that understanding theoretical level is a key to global security, global and state levels are also included in the analysis. The question of which level is determinant depends on the time and place (Buzan and Waever 2003).

In general terms, according to Copenhagen School historical stages of regional security can be given like (Buzan and Wæver 2003):

1. Modern Era (1500-1945): At this stage, world political system enlarged region by region until it globalized and independent regions disappeared. 
2. Cold War and Post -Colonial Era: (1945-1989): New regional relations started to be established among new states. However bi-polar system determined these relations. In this era, Middle East, Africa and Asia emerged as new regions.

3. Post-Cold War Era: The end of the Cold War affected regional security in three ways:

i. Overlay (determination of the superpower rivalry) disappeared and new regions like Eastern Europe, North Eastern Asia, Eastern Mediterranean have emerged.

ii. With the end of ideological rivalries, Third World countries started to unveil their own dynamics but this "freedom" is counterbalanced by the economic dominance of the center.

iii. The security issues apart from military issues started to come into world agenda.

Instead of defining the concepts of region and regionalism in a static way, it could be helpful to think that regions constantly emerge, shape and disappear according to the political, economic and cultural factors (Levis and Wigen 1997, as cited in Vayrynen 2003: 25). In this way, a region can be defined by physically politically, economically (Vayrynen 2003: 26) and also by a combination of all these.

\section{Conclusion}

In contemporary era, regionalism is gaining importance in many dimensions. First, it offers a level of analysis that all factors of an issue can be observed. Second, it can be accepted as a confronting area of two contradictory trends of globalization and localization. Third, it is a leverage or a control mechanism in parallel with the widening and deepening of multi-dimensional security structure. That is to say that in order to resolve a conflict and ensure stability (in Syria or in Libya for instance) regional constructions are required rather than interstate and/or global arrangements. Fourth, in relation regionalism has a potential to provide a basis for regional constitutional initiations. That of course would be a new political structuring that barely witnessed through political history.

On the other hand, as being an operational level of revisionist strategies, regionalism provides a legitimacy ground for global actors. Within this framework, regionalism becoming an inseparable part of today's security notions and practices. In contrast with the previous eras, in addition to states (as main actors), some legal or illegal groups gain importance as much as they are included in geopolitical projects. However, the mentioned legal or illegal groups gain function as a result of ex-regional actors' policies rather than their own capacity of being an actor. It can be argued that instead of the regional security complexes which were arranged according to the balance of power principle and nation-states as the basic actors; today regionalism is a leverage and a legitimacy ground for the 
construction of a cosmopolitan regional security community. Therefore, a regional perspective in all aspects that mentioned in this study may help to analyze today's international security structure. Finally, it can be claimed that new regionalism is the new arena for both pros and opponents of regional geopolitical constructions. That is why, new regionalism may be considered as the slipknot of the two rival trends of integration and disintegration.

\section{References}

Agnew J, Corbridge S (1995) Mastering space: hegemony, territory, and international political economy. London: Routledge.

Barnett PM (2005) Pentagon's new map: war and peace in the twenty-first century. New York: G. P. Putnam's Sons.

Boals K (1973) The concept "subordinate international system: a critique. In Regional Politics and World Order, R Falk, S Mendlovitz (Eds), 399-410. San Francisco: W. H. Freeman.

Buzan B (1991) People, states, and fear: an agenda for international security studies in the post-cold war era. $2^{\text {nd }}$ Edition. London: Harvester Wheatsheaf.

Buzan B, Waever O (2003) Regions and powers: the structure of international security. Cambridge: Cambridge University Press.

Buzan B, Jones C, Little R (1993) The logic of anarchy: neorealism to structural realism. New York: Columbia University Press.

Caşın MH, Özgöker U, Çolak H (2007) Avrupa Birliği. [European Union]. İstanbul: Nokta Kitap.

Dieter M (2009) Changing patterns of regional governance: from security to political economy? The Pacific Review 22(1): 73-90.

Falk R, Mendlovitz S (1973) General Introduction in regional politics and world order. San Francisco: W.H. Freeman.

Farrell M, Hettne B, Langenhove LV (2005) Global politics of regionalism: theory and practice. London: Pluto Press.

Fishlow A, Haggard S (1992) The United States and the regionalization of the world economy. Paris: OECD Development Center Research Project on Globalization \& Regionalization.

Gilpin R (1981) War and change in world politics. Cambridge: Cambridge University Press.

Gunnarson M (2000) Regionalism and security - Two concepts in the wind of change. Umea. Retrieved from: https://bit.ly/2ldjjdS.

Haas EB (1958) The uniting of Europe: political, social, and economic forces 1950-1957. Stanford: Stanford University Press.

Hentz JJ (2003) Introduction: new regionalism and the 'Theory of security studies'. In New Critical Security and Regionalism: Beyond the Nation State, J Hentz, M Boas (Eds), 3-16. Aldershot: Ashgate.

Hettne B (2008) Teori ve pratikte güvenliğin bölgeselleşmesi [Security Regionalism in Theory and Practice]. The Journal of International Relations 18(Summer): 87-106.

Hurrell A (1995) Explaining the resurgence of regionalism in world politics. Review of International Studies 21(4): 331-358.

Hurrell A (2007) One world? Many words? The place of regions in the study of international society. International Affairs 83(1): 151-166. 
Kaplan MA (1957) System and process in international politics. New York: John Wiley and Sons.

Katzenstein PJ (2005) A world of regions: Asia and Europe in the American Imperium. Ithaca and London: Cornell University Press.

Kelly R (2007) Security theory in the new regionalism. International Studies Review 9(2): 197-229.

Korkmaz V (2010) Bölgesel güvenlik üzerine kuramsal tartışmalar. [Theoretical discussions on regional security]. SAREM, Stratejik Araştırmalar Dergisi Journal of Strategic Researches 8(15): 135-168 .

Kubicek P (2009) The commonwealth of independent states: the example of failed regionalism? Review of International Studies 35(S1): 237-256.

Levis MW, Wigen KE (1997) The myth of continents: a critique of metageography. Berkeley: University of California Press.

Mansfield ED, Milner H (1999) The new wave of regionalism. International Organization 53(3): 589-627.

Mearsheimer J (2001) The tragedy of great power politics. New York: W.W. Norton.

Mittelman J, Falk R (2000) Global hegemony and regionalism. In Regionalism in the Post-Cold War World, S Calleya (Ed). Burlington: Ashgate.

Moon B (1998) Regionalism is back! Now what? Mershon International Studies Review 42(2): 338-342.

Newman D (1999) Boundaries, territory, and postmodernity. London: Frank Cass.

Singer DJ (1961) The Level-of-analysis problem in international relations. World Politics 14(1): 77-92.

Thakur R, Langenhove LV (2006) Enhancing global governance through regional integration. Global Governance. A Review of Multilateralism and International Organisations 12(3): 233-240.

Thompson W (1973) The regional subsystem: a conceptual explication and propositional inventory. International Studies Quarterly 17(1): 89-117.

Toft P (2005) John J. Mearsheimer: an offensive realist between geopolitics and power. Journal of International Relations and Development 8(4): 381-408.

Vayrynen R (2003) Regionalism: old and new. International Studies Review 5(1): 25-51.

Yılmaz S (2008) Güç ve politika. [Power and politics]. İstanbul: Alfa. 